\title{
Peran Non Governmental Organization (GIZ dan LSM Bina Swadaya) terhadap Klaster Susu Sapi Perah di Kabupaten Boyolali
}

\author{
Rizky Madya Wulan 1 \\ Jurusan Perencanaan Wilayah dan Kota \\ Universitas Diponegoro, Semarang, Indonesia \\ Muhammad Muktiali \\ Jurusan Perencanaan Wilayah dan Kota \\ Universitas Diponegoro, Semarang, Indonesia
}

\begin{abstract}
Abstrak: Perubahan sistem pemerintahan di Indonesia menjadi sistem pemerintahan desentralisasi, dimana dengan perubahan sistem pemerintahan tersebut menyebabkan terjadinya kebijakan pengembangan potensi lokal melalui pengembangan ekonomi lokal (PEL). Klaster usaha merupakan salah satu bagian dari PEL. Sebagian klaster masih bersifat semi formal dimana pendekatan kepada Non Governmental Organization (NGO) masih belum dapat diterapkan sepenuhnya. Klaster susu sapi perah di Kabupaten Boyolali merupakan daerah penghasil susu terbesar di Jawa Tengah. Dalam klaster susu sapi perah menjalin kerjasama dengan GIZ dan Bina Swadaya yang merupakan suatu NGO. Tujuan dilakukannya penelitian ini adalah untuk memahami peranan yang dilakukan NGO (GIZ dan Bina Swadaya) dalam klaster dan mengukur efektivitas peran yang dilakukan NGO tersebut dalam klaster susu sapi perah di Kabupaten Boyolali. Untuk mencapai tujuan tersebut, pendekatan penelitian yang digunakan yaitu pendekatan mix method dimana dalam proses penelitian ini mencoba menggabungkan antara pendekatan kuantitatif dan pendekatan kualitatif. Penelitian ini berfokus pada pemahaman peran yang dilakukan NGO dalam klaster, pengukuran efektivitas peran NGO dalam klaster, serta dampak yang dirasakan dari peranan yang dilakukan NGO dalam klaster. Dari proses analisis tersebut didapat sebuah kesimpulan dan rekomendasi mengenai peran Non Governmental Organization (GIZ dan Bina Swadaya) terhadap klaster susu sapi perah di Kabupaten Boyolali.
\end{abstract}

Kata kunci: efektivitas, non governmental organization (NGO), peran

\begin{abstract}
The system change of government in Indonesia to a decentralized government system leads to the potential development of local policies through local economic development (LED). Cluster is one part of the local economic development (LED). Most of the cluster is still in semi-formal form where the approach to the Non Governmental Organization (NGO) still can not be fully implemented. Cluster milk of dairy cows in Boyolali is the largest milk producing areas in Central Java. In the cluster of dairy cows formed a partnership with GIZ and Bina Swadaya which is a NGO. The purpose of this study was undertaken to understand the role of NGOS (GIZ and Bina Swadaya) in the cluster and measure the effectiveness of the role of NGOs is done in a cluster of dairy cows in Boyolali. To achieve the objectives, the research approach used is mix method approach where the process of the study sought to combine quantitative and qualitative approaches. This research focuses on understanding the role of NGOs in the cluster performed, measuring the
\end{abstract}

\footnotetext{
1 Korespondensi Penulis: : Jurusan Perencanaan Wilayah dan Kota, Universitas Diponegoro, Semarang

Email: rizkymadyawulan@yahoo.com
} 
effectiveness of the role of NGOs in the cluster, as well as the implications of the NGOs role in the cluster performed. The analysis process resulted into a conclusion and recommendations on the role of Non Governmental Organization (GIZ and Bina Swadaya) Against Milk Dairy Cluster in Boyolali.

Keywords: effectiveness, non governmental organization (NGO), role

\section{Pendahuluan}

Perubahan sistem pemerintahan di Indonesia dari sistem pemerintahan sentralistik menjadi sistem pemerintahan desentralisasi. Dari perubahan sistem pemerintahan tersebut, masingmasing pemerintah daerah dituntut untuk mengembangkan daerahnya agar dapat bersaing dengan daerah lain melalui pengembangan ekonomi lokal (PEL). Terdapat tiga strategi pendekatan dalam pengembangan ekonomi lokal yaitu pengembangan daya saing lokal, pengembangan klaster usaha, dan pengembangan kelembagaan. Dari ketiga strategi pendekatan tersebut, pengembangan klaster usaha lebih banyak diterapkan pada suatu daerah untuk mengembangkan potensi lokal yang ada. Klaster merupakan konsentrasi dari kegiatan ekonomi yang saling terkait dan lembaga penunjangnya, untuk jenis kegiatan ekonomi yang saling berkaitan, sebagai strategi untuk meningkatkan daya saing (Porter, 1998).

Adanya kerjasama yang dilakukan pemerintah daerah dengan institusi pendukung seperti LSM atau Non Govermental Organization (NGO) dalam pengembangan klaster menjadi menarik untuk diteliti. Dengan pelibatan kerjasama tersebut, pengembangan klaster dapat berjalan lebih efektif dan efisien karena setiap aktor yang terlibat memiliki peran dan fungsinya masing-masing. Dalam era otonomi daerah sekarang ini yang ditandai dengan sistem pemerintahan desentralisasi, peran NGO dirasa cukup penting untuk mendukung tercapainya tujuan otonomi daerah. Dimana tujuan otonomi daerah yaitu menggali potensi lokal yang dimiliki suatu daerah untuk meningkatkan kesejahteraan masyarakat (Karsidi, 2001).

Klaster susu sapi perah di Kabupaten Boyolali merupakan daerah penghasil susu terbesar di Jawa Tengah. Untuk lebih mengembangkan potensi dan produk unggulan Kabupaten Boyolali, maka Forum for Economic Development and Employment Promotion (FEDEP) Boyolali berkerjasama dengan Forum Pengembangan Ekonomi dan Sumber Daya (FPESD) Jawa Tengah, Deutsche Gesellschaft für Technische Zusammenarbeit-Regional Economic Development (GTZ-RED), dan Pemerintah Kabupaten Boyolali membentuk Klaster Susu Sapi Perah pada tahun 2006, melalui Workshop Pembentukan Klaster dan dilanjutkan dengan Workshop Penyusunan Program dan Pengurus Klaster. Dalam pelaksanaannya Forum Klaster Susu Sapi Perah menjalin kerjasama dengan FEDEP Boyolali, Dinas Peternakan, Bina Swadaya, GTZ-RED serta DED (Deutscher Entwicklungsdienst) Indonesia. Adanya NGO yang terlibat seperti GTZ-RED, DED Indonesia, dan Bina Swadaya dalam klaster susu sapi perah ini menarik untuk dikaji, terkait dengan teori yang mengatakan bahwa peran NGO dalam pengembangan klaster sangat penting terutama dalam hal pemberdayaan klaster dan advokasi. Namun untuk GTZRED dan DED Indonesia merupakan bagian dari GIZ (Gesellschaft fur Internasionale Zusammenarbeit) dan sekarang telah tergabung menjadi satu kelembagaan dengan nama GIZ. 


\section{Kajian Teori}

\section{Pengertian Klaster}

Definisi klaster telah banyak sekali dikemukakan oleh berbagai pihak, namun secara umum klaster dalam bahasa sederhana diartikan sebagai kelompok. Mengacu pada Porter yang mengatakan bahwa klaster adalah konsentrasi dari kegiatan ekonomi yang saling terkait dan lembaga penunjangnya untuk jenis kegiatan ekonomi yang saling berkaitan sebagai strategi untuk meningkatkan daya saing (Porter, 1998). Selain itu, pengertian klaster menurut Mendagri (2009) adalah sekelompok perusahaan-perusahaan, pemasok dan industri terkait yang saling berhubungan serta institusi-institusi yang berspesialisasi di bidang tertentu yang berada pada lokasi-lokasi tertentu (konsetrasi geografis).

Dari beberapa pengertian klaster yang telah dikemukakan diatas, maka dapat diambil kesimpulan bahwa klaster adalah suatu pengelompokkan usaha berdasarkan kesamaan sektor atau bidang yang bergerak dalam satu wilayah yang berdekatan atau konsentrasi geografis dengan ditandai adanya hubungan antar usaha dan didukung dengan lembaga lembaga penunjang sehingga dapat meningkatkan daya saing suatu daerah.

\section{Pengertian Non-Governmental Organization (NGO)}

Pada umumnya NGO merupakan sebuah organisasi yang didirikan oleh perorangan atau sekelompok orang yang secara sukarela memberikan pelayanan kepada masyarakat umum tanpa bertujuan untuk memperoleh keuntungan dari kegiatannya (Praja, 2009). NGO menurut Nugroho (2001) merupakan suatu lembaga, kelompok, atau organisasi yang aktif dalam mengupayakan pemberdayaan masyarakat dan pembangunan terutama pada lapisan masyarakat bawah. Menurut ensiklopedi online Wikipedia (dalam Praja, 2009) menterjemahkan NGO merupakan sebuah organisasi yang bukan menjadi bagian dari pemerintah, birokrasi, ataupun negara. NGO memiliki ciri-ciri sebagai berikut:

a. Organisasi yang bukan bagian dari pemerintah, birokrasi, ataupun negara

b. Dalam melakukan kegiatannya, organisasi ini tidak berorientasi pada keuntungan

c. Kegiatan yang dilakukan untuk kepentingan masyarakat umum, tidak hanya untuk kepentingan anggota seperti yang dilakukan koperasi ataupun organisasi profesi lainnya

\section{Peran Non-Governmental Organization (NGO)}

Dalam era otonomi daerah, NGO memiliki peran yang cukup penting dalam mendukung tercapainya tujuan otonomi daerah. Tujuan otonomi daerah yaitu menggali potensi lokal yang dimiliki daerah untuk meningkatkan kesejahteraan masyarakat. Peran NGO dalam otonomi daerah dibedakan menjadi 2 (Karsidi, 2001) yaitu:

a. Peranan Makro

Dalam otonomi daerah peranan makro yang dapat dilakukan NGO adalah berusaha menjaga independensi dan mengembangkan kemandirian organisasi. Peran tersebut dapat dilakukan dengan cara:

- Mendirikan kembali lembaga-lembaga independen di berbagai level daerah

- Mencoba mengembangkan mekanisme kerja yang mengarah pada fungsi kontrol terhadap aktivitas pemerintah

- Menyebarluaskan (dissemination) berbagai informasi yang masih menjadi masalah yang dihadapi

b. Peranan Mikro

Peranan mikro yang dapat dilakukan NGO dalam era otonomi daerah yaitu memfasilitasi kelompok-kelompok masyarakat miskin dalam mengembangkan 
kemampuan, memecahkan masalah, serta mengelola sumber daya disekitarnya menuju kemandirian ekonomi lokal. Peran tersebut dapat dilakukan dengan cara:

- Mengembangkan daya saing

- Membantu pelaku ekonomi rakyat melepaskan diri dari isolasi yaitu dengan masuk ke dalam jaringan pasar

- Mengembangkan kemandirian kelembagaan

NGO baik yang terlibat secara langsung (Business Development Service) atau yang tidak terlibat langsung memiliki peran besar dalam 2 kategoori, yaitu (Menteri Dalam Negeri 2009):

a. Pemberdayaan pelaku usaha sebagai produsen

Pemberdayaan tersebut dilakukan melalui pengorganisasian dan pendampingan dalam klaster seperti manajemen, peningkatan kualitas, dan pemasaran.

b. Advokasi

Advokasi yang dilakukan NGO seperti penyadaran akan hak dan kontrol atas kebijakan pemerintah daerah yang merugikan pelaku usaha.

Menurut Willis (2005) peran-peran yang dilakukan NGO khususnya dalam pembangunan di masyarakat golongan bawah berorientasi atau mengacu pada:

a. Kesejahteraan masyarakat dan penyediaan pelayanan

b. Bantuan darurat

c. Pengembangan pendidikan

d. Partisipasi dan pemberdayaan

e. Swasembada

f. Advokasi

g. Jaringan

\section{Dampak Peran Non-Governmental Organization (NGO)}

Dari peran yang dilakukan NGO tersebut membawa peran yang positif. Berikut merupakan dampak dari positif dari keberadaan NGO (Ismawan, 2003):

a. Dampak Sosial

Melalui pengetahuan (knowledge) yang diberikan oleh NGO kepada masyarakat, diharapkan wawasan pemikiran masyarakat semakin meningkat sehingga masyarakat memiliki kemampuan untuk memikirkan banyak alternatif dalam usaha mencukupi kebutuhan hidup. Peningkatan pengetahuan yang diberikan kepada masyarakat dapat melalui dua jalur, yaitu jalur langsung dan tidak langsung. Peningkatan pengetahuan secara langsung terjadi apabila masyarakat mendapatkan penyuluhan, pelatihan, konsultasi, dan sebagainya. Sedangkan peningkatan pengetahuan secara tidak langsung terjadi sejalan dengan terintegrasinya masyarakat dalam suatu kelompok swadaya. Melalui peran yang dilakukan NGO, intervensi pembinanaan dapat membantu pemecahan permasalahan sosial yang terdapat dalam kelompok. Akibatnya penanganan masalah tersebut dapat dilakukan secara tepat sasaran dan lebih tuntas. Di samping itu, interaksi yang intensif dapat menyebabkan terjadinya proses transformasi sosial.

b. Dampak Ekonomi

Dalam bidang ekonomi, intervensi pembinaan mampu mendorong masyarakat untuk melakukan pemupukan modal. Selama ini faktor tidak berhasilnya masyarakat dalam memperbaiki kehidupannya adalah masyarakat tidak mampu melakukan pemupukan modal yang dapat digunakan sebagai pengembangan usaha. Dengan sistem kelompok, modal yang kecil dari setiap masyarakat dapat dikembangkan dan dapat dipergunakan sebagai modal usaha. Di samping itu, dengan adanya modal yang terkumpul dapat 
mengundang partisipasi dana yang lebih lebih besar dari pihak ketiga. Kemampuan permodalan kelompok yang semakin bertambah memberikan peluang semakin besar untuk mengembangkan usaha produktif.

c. Dampak Kemasyarakatan

Proses interaksi di dalam kelompok semakin meningkatkan wawasan pemikiran. Adanya kelompok sebagai wadah aktualisasi masyarakat menyebabkan keterlibatan masyarakat dalam proses pembangunan. Kesadaran untuk turut berperan aktif dalam kegiatan kelompok mempunyai dampak lebih lanjut, yaitu adanya kesediaan masyarakat atau kelompok untuk berpartisipasi dalam program-program pembangunan yang ditawarkan pemerintah. Proses pengembangan kemandirian dan kesadaran berpartisipasi telah menjembatani kesenjangan sosial di tingkat lokal. Dengan menyempitnya kesenjangan sosial berarti stabilitas sosial politik pun dapat terus berlanjut.

\section{Pengukuran Efektivitas Organisasi}

Penilaian dampak efektivitas organisasi dilakukan dengan membuat pertanyaan dasar tentang penilaian diri. Dalam mengukur efektivitas organisasi terdapat hal-hal yang harus diperhatikan, yaitu (Beer, 2003):

a. Melakukan penilaian peran

Penilaian efektivitas organisasi dilakukan dengan metode penskalaan, dimana pada skala tertinggi berarti peran yang dilakukan berdampak besar sedangkan skala terendah menandakan bahwa tidak ada pengaruh atau tidak berdampak apa-apa dari peran yang dilakukan tersebut.

b. Mengidentifikasi hambatan untuk mencapai efektivitas

Dalam mengidentifikasi hambatan untuk mencapai efektivitas, responden diminta untuk menunjukan faktor-faktor yang menghambat efektivitas kinerja organisasi.

c. Melakukan penilaian terhadap peran yang paling efektif

Penilaian peran merupakan salah satu cara yang dapat digunakan untuk menemukan tindakan atau strategi yang dianggap paling efektif. Dalam penilaian peran ini, responden diminta untuk mengajukan kegiatan atau program yang dilakukan organisasi yang dirasa paling efektif.

Untuk mengukur efektivitas peran Non Governmental Organization (GIZ dan Bina Swadaya) dalam klaster susu sapi perah menggunakan skala likert. Instrumen penelitian yang digunakan dalam skala likert dibuat dalam bentuk checklist.

Tabel 1. Penilaian Efektivitas Peran yang Digunakan

\begin{tabular}{c|l|c|c|c}
\hline No. & Pernyataan & Skor & $\begin{array}{c}\text { Penilaian Efektivitas Peran } \\
\text { GIZ (Range Nilai) }\end{array}$ & $\begin{array}{c}\text { Penilaian Efektivitas } \\
\text { Peran Bina Swadaya } \\
\text { (Range Nilai) }\end{array}$ \\
\hline 1. & Efektif & 3 & $3008<$ skor $<4512$ & $2256<$ skor $<3384$ \\
\hline 2. & Cukup Efektif & 2 & $1504<$ skor $<3008$ & $1128<$ skor $<2256$ \\
\hline 3. & Tidak Efektif & 1 & $<1504$ & $<11$ \\
\hline
\end{tabular}

\section{Metode Penelitian}

Penelitian ini dilakukan dengan tujuan untuk memahami peranan NGO (GIZ dan Bina Swadaya) serta mengukur efektivitas peranan NGO (GIZ dan Bina Swadaya) tersebut 
dalam klaster susu sapi perah di Kabupaten Boyolali. Untuk mencapai tujuan tersebut, pendekatan penelitian yang digunakan adalah pendekatan mix method (metode campuran) yaitu suatu pendekatan yang dapat menerapkan teori secara deduktif (peneliti kuantitatif) dan induktif (peneliti kualitatif) serta dalam penelitian ini dapat diawali dengan perspektif teori (Creswell, 2010). Pemilihan pendekatan mix method yang digunakan dalam penelitian yaitu karena dalam penelitian ini bertujuan untuk memperoleh pemahaman dari peranan yang dilakukan NGO (GIZ dan Bina Swadaya) dalam klaster kemudian mencoba menguji efektivitas peranan tersebut dari teori yang telah ada.

Pendekatan mix method dalam penelitian ini menggunakan strategi penelitian berupa strategi triangulasi konkuren. Strategi ini menerapkan metode kuantitatif dan metode kualitatif secara terpisah untuk menutupi atau menyeimbangkan kelemahan dari satu metode dengan kelebihan pada satu metode atau sebaliknya (Creswell, 2012). Dalam strategi ini pencampuran metode terjadi pada tahap interpretasi dan pembahasan. Pencampuran tersebut dilakukan dengan menggabungkan dua data penelitian atau dengan mengintegrasikan dan mengomparasikan hasil dari dua data tersebut dalam pembahasan.

\section{Gambaran Umum Klaster Susu Sapi Perah}

Ikon Kabupaten Boyolali sebagai 'kota susu', karena memang telah terbukti bahwa Boyolali menjadi kabupaten penghasil susu terbesar di Jawa Tengah. Terdapat 6 kecamatan penghasil susu antara lain Kecamatan Selo, Cepogo, Musuk, Ampel, Boyolali dan Mojosongo. Pada tahun 2009, keenam kecamatan tersebut pernah menghasilkan susu hingga \pm 100 ton per hari. Oleh karena itu, sektor persusuan merupakan sektor yang cukup diperhitungkan kontribusinya dalam pertumbuhan ekonomi Kabupaten Boyolali. Hal ini karena susu merupakan produk unggulan Kabupaten Boyolali.

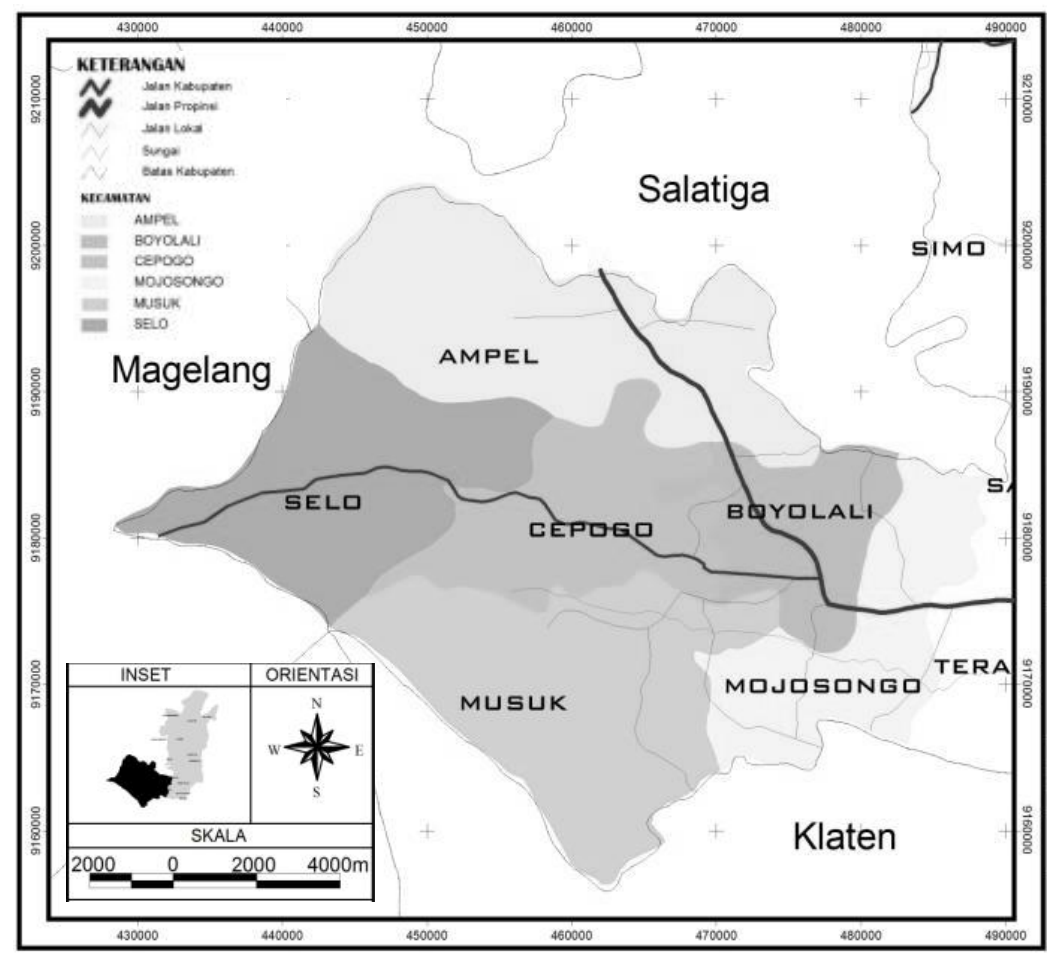

Gambar 1. Peta Lokasi Klaster Susu Sapi Perah 
Klaster susu sapi perah dibentuk pada tahun 2006 dengan tujuan untuk mengembangkan potensi dan produk unggulan yang dimiliki Kabupaten Boyolali. Pembentukkan klaster tersebut dilakukan melalui Workshop Pembentukan Klaster Susu Sapi Perah dan dilanjutkan dengan Workshop Penyusunan Program dan Pengurus Klaster. Dalam pelaksanaannya Forum Klaster Susu Sapi Perah menjalin kerjasama dengan FEDEP Boyolali, Disnakkan Kabupaten Boyolali, LSM Bina Swadaya, GTZ-RED dan DED Indonesia. Dalam pengembangan klaster susu sapi perah memiliki banyak kendala dan permasalahan. Beberapa permasalahan yang ada dalam klaster susu sapi perah yaitu antara lain modal, pemasaran, kualitas susu masih rendah, serta perilaku peternak yang sulit diubah.

\section{Analisis Efektivitas Peran Non-Governmental Organization (GIZ dan Bina Swadaya) terhadap Klaster Susu Sapi Perah}

\section{Analisis Peran dan Efektivitas Peran NGO dalam Klaster Susu Sapi Perah}

\section{A. Analisis Peran dan Efektivitas Peran GIZ dalam Klaster Susu Sapi Perah}

Sasaran dari keterlibatan GIZ dalam klaster yaitu dapat memperbaiki kondisi kehidupan penduduk lokal melalui peningkatan proses pengembangan ekonomi lokal daerah yang berbasis pada pengentasan kemiskinan. Dari sasaran tersebut, peranan GIZ dalam klaster terbagi menjadi 2 yaitu peranan makro dan peranan mikro. Berikut peranan dan penilaian efektivitas peranan makro dan peranan mikro yang dilakukan GIZ dalam klaster susu sapi perah:

- Peran Makro

a. Pembelaan hak peternak dalam klaster

Peran GIZ dalam pembelaan hak peternak ditujukan untuk memberikan pengetahuan atau pemikiran kepada para peternak dalam mendapatkan apa yang menjadi haknya sebagai pelaku usaha dalam klaster susu sapi perah. Dalam peranan ini, GIZ melakukan pengembangan pengetahuan peternak serta mengadakan pertemuan antar peternak. Selain mengembangkan pengetahuan, dalam peranan ini GIZ mengadakan pertemuan dengan para peternak. Berikut penilaian efektivitas peran yang dilakukan GIZ dalam pembelaan hak pelaku usaha:

Tabel 2. Penilaian Efektivitas Peran GIZ dalam Pembelaan Hak Peternak

\begin{tabular}{|c|c|c|c|c|c|c|}
\hline \multirow[b]{2}{*}{ No. } & \multirow{2}{*}{$\begin{array}{c}\text { Kegiatan Yang } \\
\text { dilakukan }\end{array}$} & \multicolumn{3}{|c|}{ Penilaian Efektivitas Responden } & \multirow[b]{2}{*}{$\begin{array}{l}\text { Total Skor } \\
\text { Responden }\end{array}$} & \multirow[b]{2}{*}{ Kesimpulan } \\
\hline & & $\begin{array}{c}\text { Skor 1 } \\
\text { (tidak efektif) }\end{array}$ & $\begin{array}{c}\text { Skor 2 } \\
\text { (cukup efektif) }\end{array}$ & $\begin{array}{c}\text { Skor 3 } \\
\text { (efektif) }\end{array}$ & & \\
\hline 1. & $\begin{array}{l}\text { Pengembangan } \\
\text { pengetahuan } \\
\text { peternak melalui } \\
\text { transfer } \\
\text { pengetahuan }\end{array}$ & $\begin{array}{c}9, \text { jadi } \\
9 \times 16= \\
144\end{array}$ & $\begin{array}{c}79, \text { jadi } 76 \times 32 \\
=2528\end{array}$ & $\begin{array}{c}6, \text { jadi } \\
6 \times 48= \\
288\end{array}$ & 2960 & $\begin{array}{l}\text { Cukup } \\
\text { Efektif }\end{array}$ \\
\hline 2. & $\begin{array}{l}\text { Mengadakan } \\
\text { pertemuan diantar } \\
\text { peternak }\end{array}$ & $\begin{array}{c}21, \text { jadi } \\
21 \times 16= \\
336\end{array}$ & $\begin{array}{c}65, \text { jadi } \\
65 \times 32= \\
2080\end{array}$ & $\begin{array}{c}8, \text { jadi } \\
8 \times 48= \\
384\end{array}$ & 2800 & $\begin{array}{l}\text { Cukup } \\
\text { Efektif }\end{array}$ \\
\hline \multicolumn{5}{|c|}{ Rata-rata } & 2880 & $\begin{array}{l}\text { Cukup } \\
\text { efektif }\end{array}$ \\
\hline
\end{tabular}

Dari penilaian efektivitas peran GIZ dalam pembelaan hak peternak dalam klaster diatas dinilai cukup efektif. Masih kecilnya dampak yang dirasakan peternak dari kegiatan 


\section{Peran Non Governmental Organization (GIZ dan LSM Bina Swadaya) terhadap Klaster Susu Sapi Perah}

yang dilakukan GIZ terkait dengan pembelaan hak pelaku usaha membuat para peternak memberikan penilaian cukup efektif. Hal ini karena peranan yang dilakukan GIZ belum dapat dirasakan oleh setiap peternak sapi perah yang ada di Kabupaten Boyolali.

b. Pembelaan hak peternak dalam klaster

Dalam peran memberikan informasi yang menjadi masalah dalam klaster, GIZ melakukan kegiatan-kegiatan seperti melakukan uji kualitas susu, memberikan penyuluhan pada kegiatan apel sapi, melakukan pembuatan film panduan ternak sapi perah, serta melakukan inisiasi pembuatan silase sebagai alternatif pakan ternak. Sebelum terlibat dalam klaster susu sapi perah, GIZ melakukan uji kualitas susu untuk mengetahui permasalahan yang dihadapi klaster. Setelah diketahui permasalahannya yaitu terletak pada kualitas susu, GIZ memberikan pembinaan dan pelatihan untuk menekan peningkatan kualitas susu yang dihasilkan. Berikut penilaian efektivitas peran yang dilakukan GIZ dalam memberikan informasi yang menjadi permasalahan dalam klaster:

Tabel 3. Penilaian Efektivitas Peran GIZ dalam Pemberian Informasi dalam Klaster

\begin{tabular}{|c|c|c|c|c|c|c|}
\hline \multirow[b]{2}{*}{ No. } & \multirow[b]{2}{*}{$\begin{array}{c}\text { Kegiatan Yang } \\
\text { dilakukan }\end{array}$} & \multicolumn{3}{|c|}{ Penilaian Efektivitas Responden } & \multirow[b]{2}{*}{$\begin{array}{l}\text { Total Skor } \\
\text { Responden }\end{array}$} & \multirow[b]{2}{*}{ Kesimpulan } \\
\hline & & $\begin{array}{c}\text { Skor 1 } \\
\text { (tidak efektif) }\end{array}$ & $\begin{array}{c}\text { Skor 2 } \\
\text { (cukup efektif) }\end{array}$ & $\begin{array}{r}\text { Skor 3 } \\
\text { (efektif) }\end{array}$ & & \\
\hline 1. & \begin{tabular}{|l|l} 
melakukan uji \\
kualitas susu yang \\
ada di Kabupaten \\
Boyolali \\
\end{tabular} & $\begin{array}{c}16, \text { jadi } \\
16 \times 16= \\
256\end{array}$ & $\begin{array}{l}66 \text {, jadi } \\
66 \times 32 \\
=2112\end{array}$ & $\begin{array}{c}12, \text { jadi } \\
12 \times 48= \\
7576\end{array}$ & 2944 & Cukup Efektif \\
\hline 2. & \begin{tabular}{|c|}
\multicolumn{2}{|c|}{ memberikan } \\
penyuluhan pada \\
kegiatan apel sapi
\end{tabular} & $\begin{array}{c}5, \text { jadi } \\
5 \times 16= \\
80 \\
\end{array}$ & $\begin{array}{l}74, \text { jadi } \\
74 \times 32 \\
=3168 \\
\end{array}$ & $\begin{array}{c}15, \text { jadi } \\
15 \times 48= \\
720\end{array}$ & 3168 & Cukup Efektif \\
\hline 3. & $\begin{array}{l}\text { pembuatan film } \\
\text { panduan ternak } \\
\text { sapi perah }\end{array}$ & $\begin{array}{c}5, \text { jadi } \\
5 \times 16= \\
80\end{array}$ & $\begin{array}{l}64, \text { jadi } \\
64 \times 32 \\
=2048 \\
\end{array}$ & $\begin{array}{c}25, \text { jadi } \\
25 \times 48= \\
1200\end{array}$ & 3328 & Efektif \\
\hline 4. & $\begin{array}{l}\text { inisiasi pembuatan } \\
\text { silase sebagai } \\
\text { alternatif pakan } \\
\text { ternak }\end{array}$ & $\begin{array}{c}34, \text { jadi } \\
34 \times 16= \\
544\end{array}$ & $\begin{array}{c}55, \text { jadi } \\
55 \times 32= \\
1760\end{array}$ & $\begin{array}{c}5, \text { jadi } \\
5 \times 48= \\
240\end{array}$ & 2544 & Cukup efektif \\
\hline \multicolumn{5}{|c|}{ Rata-Rata } & 2996 & Cukup efektif \\
\hline
\end{tabular}

Dari penilaian efektivitas di atas, diketahui bahwa peran yang dilakukan GIZ dalam pemberian informasi yang menjadi masalah dalam klaster dinilai cukup efektif. Hal ini karena peranan yang dilakukan GIZ dalam memberikan informasi yang menjadi masalah dalam klaster memberikan dampak yaitu para peternak maupun stakeholder lain yang terkait dalam klaster susu dapat mengetahui apa yang menjadi permasalahan dalam klaster yang kemudian secara bersama-sama dapat dibuat suatu kegiatan untuk dapat menanggulangi permasalahan tersebut.

- Peran Mikro

a. Peningkatan daya saing

Peningkatan daya saing yang dilakukan GIZ yaitu dengan membuat produk olahan susu atau melakukan pengolahan pasca produksi. Project pengolahan pasca produksi yaitu dengan melakukan produksi sabun susu dan produksi keju. Selain untuk dapat meningkatan daya saing daerah, pengolahan pasca produksi tersebut ditujukan untuk dapat meningkatkan nilai susu. Berikut penilaian efektivitas peran GIZ dalam peningkatan daya saing: 
Tabel 4. Penilaian Efektivitas Peran GIZ dalam Peningkatan Daya Saing

\begin{tabular}{|c|c|c|c|c|c|c|}
\hline \multirow[b]{2}{*}{ No. } & \multirow[b]{2}{*}{$\begin{array}{l}\text { Kegiatan yang } \\
\text { dilakukan }\end{array}$} & \multicolumn{3}{|c|}{ Penilaian Efektivitas Responden } & \multirow[b]{2}{*}{$\begin{array}{l}\text { Total Skor } \\
\text { Responden }\end{array}$} & \multirow[b]{2}{*}{ Kesimpulan } \\
\hline & & $\begin{array}{c}\text { Skor } 1 \\
\text { (tidak efektif) }\end{array}$ & $\begin{array}{c}\text { Skor } 2 \\
\text { (cukup efektif) }\end{array}$ & $\begin{array}{c}\text { Skor } 3 \\
\text { (efektif) }\end{array}$ & & \\
\hline 1. & $\begin{array}{l}\text { Melakukan project } \\
\text { pasca produksi } \\
\text { melalui sabun susu }\end{array}$ & $\begin{array}{c}24, \text { jadi } \\
24 \times 16= \\
384\end{array}$ & $\begin{array}{l}65, \text { jadi } \\
65 \times 32 \\
=2080\end{array}$ & $\begin{array}{c}5, \text { jadi } \\
5 \times 48= \\
240\end{array}$ & 2704 & Cukup Efektif \\
\hline 2. & $\begin{array}{l}\text { Melakukan project } \\
\text { pasca produksi } \\
\text { melalui keju }\end{array}$ & $\begin{array}{c}0, \text { jadi } \\
0 \times 16= \\
0 \\
\end{array}$ & $\begin{array}{l}40, \text { jadi } \\
40 \times 32 \\
=1280\end{array}$ & $\begin{array}{c}54, \text { jadi } \\
54 \times 48= \\
2592 \\
\end{array}$ & 3872 & Efektif \\
\hline \multicolumn{5}{|c|}{ Rata-rata } & 3228 & Efektif \\
\hline
\end{tabular}

Dari tabel penilaian efektivitas peran GIZ dalam peningkatan daya saing di atas menunjukan bahwa peran yang dilakukan GIZ dinilai efektif terutama pada project pasca produksi melalui keju. Hal ini karena untuk dari project produksi keju tersebut dapat meningkatkan nilai jual susu. Namun pada kegiatan project pasca produksi melalui sabun susu, sebanyak 65 responden menilai cukup efektif , hal ini karena project produksi sabun saat ini tidak beroperasi karena terkendala pada izin usaha.

b. Pengembangan kemandirian lembaga

Pengembangan kemandirian lembaga merupakan suatu upaya untuk mendukung klaster dari sisi kelembagaannya. Pengembangan kemandirian lembaga yang dilakukan GIZ yaitu dengan melakukan pemerkuat koperasi primer dan klaster susu. Dalam peran pengembangan kemandirian lembaga, GIZ melakukan kegiatan seperti uji kualitas susu, peningkatan jaringan antar pelaku persusuan, pelatihan dan transfer teknologi pada pihak KUD, evaluasi kualitas susu dan kontrol kualitas susu. Berikut penilaian efektivitas peran yang dilakukan GIZ dalam pengembangan kemandirian lembaga:

Tabel 5. Penilaian Efektivitas Peran GIZ dalam Pengembangan Kemandirian Lembaga

\begin{tabular}{|c|c|c|c|c|c|c|}
\hline \multirow[b]{2}{*}{ No } & \multirow[b]{2}{*}{$\begin{array}{l}\text { Kegiatan Yang } \\
\text { dilakukan }\end{array}$} & \multicolumn{3}{|c|}{ Penilaian Efektivitas Responden } & \multirow[b]{2}{*}{$\begin{array}{l}\text { Total Skor } \\
\text { Responden }\end{array}$} & \multirow[b]{2}{*}{ Kesimpulan } \\
\hline & & $\begin{array}{c}\text { Skor 1 } \\
\text { (tidak efektif) }\end{array}$ & $\begin{array}{c}\text { Skor } 2 \\
\text { (cukup efektif) }\end{array}$ & $\begin{array}{l}\text { Skor } 3 \\
\text { (efektif) }\end{array}$ & & \\
\hline 1. & $\begin{array}{l}\text { uji kualitas susu } \\
\text { ditingkat KUD }\end{array}$ & $\begin{array}{c}10, \text { jadi } \\
10 \times 16= \\
160\end{array}$ & $\begin{array}{l}73, \text { jadi } \\
73 \times 32 \\
=2336\end{array}$ & $\begin{array}{c}11, \text { jadi } \\
11 \times 48= \\
528\end{array}$ & 3024 & Cukup Efektif \\
\hline 2. & $\begin{array}{l}\text { peningkatan } \\
\text { jaringan antar } \\
\text { pelaku persusuan }\end{array}$ & $\begin{array}{c}16, \text { jadi } \\
16 \times 16= \\
256\end{array}$ & $\begin{array}{l}69, \text { jadi } \\
69 \times 32 \\
=2208\end{array}$ & $\begin{array}{c}9, \text { jadi } \\
9 \times 48= \\
432\end{array}$ & 2896 & Cukup efektif \\
\hline 3. & $\begin{array}{l}\text { pelatihan dan } \\
\text { transfer teknologi } \\
\text { pada pihak KUD }\end{array}$ & $\begin{array}{c}7, \text { jadi } \\
7 \times 16= \\
112\end{array}$ & $\begin{array}{l}73, \text { jadi } \\
73 \times 32 \\
=2336 \\
\end{array}$ & $\begin{array}{c}14, \text { jadi } \\
14 \times 48= \\
672 \\
\end{array}$ & 3120 & Efektif \\
\hline 4. & $\begin{array}{ll}\text { evaluasi } & \text { kualitas } \\
\text { susu } & \end{array}$ & $\begin{array}{c}10, \text { jadi } \\
10 \times 16= \\
160\end{array}$ & $\begin{array}{l}76, \text { jadi } \\
76 \times 32 \\
=2432\end{array}$ & $\begin{array}{c}8, \text { jadi } \\
8 \times 48= \\
384\end{array}$ & 2976 & Cukup efektif \\
\hline 5. & $\begin{array}{ll}\text { kontrol kualitas } \\
\text { susu }\end{array}$ & $\begin{array}{c}12, \text { jadi } \\
12 \times 16= \\
192\end{array}$ & $\begin{array}{l}82, \text { jadi } \\
82 \times 32 \\
=2624\end{array}$ & $\begin{array}{c}0, \text { jadi } \\
0 \times 48= \\
0\end{array}$ & 2816 & Cukup efektif \\
\hline \multicolumn{5}{|c|}{ Rata-rata } & 2996 & Cukup efektif \\
\hline
\end{tabular}

Dari tabel penilaian efektivitas diatas, menunjukkan bahwa peran GIZ dalam pengembangan kemandirian lembaga dinilai cukup efektif. Dalam peranan pengembangan 


\section{Peran Non Governmental Organization (GIZ dan LSM Bina Swadaya) terhadap Klaster Susu Sapi Perah}

kemandirian lembaga ini, GIZ berfokus pada penekanan kualitas susu di tingkat KUD. Penekanan ini dilakukan karena ingin menghasilkan susu yang lebih baik untuk bahan baku project pasca produksi. Peranan yang dilakukan GIZ dalam klaster susu sapi peran lebih pada peningkatan kualitas susu bukan pada pemberian motivasi pada pengurus klaster.

\section{c. Pemberdayaan klaster}

Pelibatan peternak dalam setiap kegiatan dalam klaster ditujukan agar peternak dapat meningkatkan dan memperbaiki kondisi persusuan sehingga peternak dapat membuat suatu rencana kegiatan pengembangan klaster. Dalam pemberdayaan klaster susu sapi perah ini, GIZ melakukan pembuatan panduan manajemen peternakan sapi perah, pembinaan dan pelatihan pengembangan produk, serta transfer pengetahuan. Berikut penilaian efektivitas peran yang dilakukan GIZ dalam pemberdayaan pelaku usaha:

Tabel 6. Penilaian Efektivitas Peran GIZ dalam Pemberdayaan Peternak

\begin{tabular}{|c|c|c|c|c|c|c|}
\hline \multirow[b]{2}{*}{ No. } & \multirow[b]{2}{*}{$\begin{array}{c}\text { Kegiatan yang } \\
\text { dilakukan }\end{array}$} & \multicolumn{3}{|c|}{ Penilaian Efektivitas Responden } & \multirow[b]{2}{*}{$\begin{array}{l}\text { Total Skor } \\
\text { Responden }\end{array}$} & \multirow[b]{2}{*}{ Kesimpulan } \\
\hline & & $\begin{array}{c}\text { Skor 1 } \\
\text { (tidak efektif) }\end{array}$ & $\begin{array}{c}\text { Skor } 2 \\
\text { (cukup efektif) }\end{array}$ & $\begin{array}{c}\text { Skor 3 } \\
\text { (efektif) }\end{array}$ & & \\
\hline 1. & $\begin{array}{l}\text { pembuatan } \\
\text { panduan } \\
\text { manajemen } \\
\text { peternakan sapi } \\
\text { perah }\end{array}$ & $\begin{array}{c}7, \text { jadi } \\
7 \times 16= \\
112\end{array}$ & $\begin{array}{l}79, \text { jadi } \\
79 \times 32 \\
=2528\end{array}$ & $\begin{array}{c}8, \text { jadi } \\
8 \times 48= \\
384\end{array}$ & 3024 & Cukup Efektif \\
\hline 2. & $\begin{array}{l}\text { pembinaan dan } \\
\text { pelatihan } \\
\text { pengembangan } \\
\text { produk }\end{array}$ & $\begin{array}{c}6, \text { jadi } \\
6 \times 16= \\
96\end{array}$ & $\begin{array}{l}71, \text { jadi } \\
71 \times 32 \\
=2272\end{array}$ & $\begin{array}{c}17, \text { jadi } \\
17 \times 48= \\
816\end{array}$ & 3184 & Efektif \\
\hline 3. & $\begin{array}{l}\text { transfer } \\
\text { pengetahuan }\end{array}$ & $\begin{array}{c}16, \text { jadi } \\
16 \times 16= \\
256\end{array}$ & $\begin{array}{l}78, \text { jadi } \\
78 \times 32 \\
=2496 \\
\end{array}$ & $\begin{array}{c}0, \text { jadi } \\
0 \times 48= \\
0 \\
\end{array}$ & 2752 & Cukup fektif \\
\hline \multicolumn{5}{|c|}{ Rata-rata } & 2987 & Cukup efektif \\
\hline
\end{tabular}

Dari penilaian efektivitas peran di atas, dinilai bahwa peran GIZ dalam pemberdayaan pelaku usaha cukup efektif. Masih kecilnya dampak yang dirasakan oleh peternak dalam peranan GIZ ini terutama pada pengembangan pendidikan ditingkat peternak melalui transfer pengetahuan. Transfer pengetahuan yang diadakan lebih cenderung menggunakan media workshop atau secara teori. Sementara itu yang dibutuhkan oleh para peternak yaitu praktik secara langsung kepada para peternak.

\section{B. Analisis Peran dan Efektivitas Peran Bina Swadaya dalam Klaster Susu Sapi Perah}

Tujuan dari keterlibatan Bina Swadaya dalam klaster susu sapi perah yaitu untuk membantu dan memberdayakan peternak dalam bidang sosial ekonomi. Dari tujuan tersebut, peranan Bina Swadaya dalam klaster terbagi menjadi 2 yaitu peranan makro dan peranan mikro. Berikut penilaian efektivitas peranan makro dan peranan mikro yang dilakukan Bina Swadaya dalam klaster susu sapi perah:

- Peran Makro

Peranan makro yang dilakukan Bina Swadaya dalam klaster yaitu melakukan kontrol kebijakan pemerintah terkait dengan klaster susu sapi perah. Dalam peran kontrol kebijakan pemerintah, Bina Swadaya melakukan kegiatan seperti mengadakan pertemuan diantar peternak, menampung aspirasi peternak terkait harapan peternak dalam sektor persusuan, serta mengadakan pertemuan dengan stakeholder yang terlibat dalam klaster. Untuk fungsi kontrol kebijakan pemerintah Bina Swadaya bekerja sama dengan FEDEP 
Boyolali. Berikut penilaian efektivitas peran Bina Swadaya dalam mengkontrol kebijakan pemerintah:

Tabel 7. Penilaian Efektivitas Peran Bina Swadaya dalam Kontrol Kebijakan Pemerintah

\begin{tabular}{|c|c|c|c|c|c|c|}
\hline \multirow[b]{2}{*}{ No } & \multirow[b]{2}{*}{$\begin{array}{l}\text { Kegiatan yang } \\
\text { dilakukan }\end{array}$} & \multicolumn{3}{|c|}{ Penilaian Efektivitas Responden } & \multirow[b]{2}{*}{$\begin{array}{l}\text { Total Skor } \\
\text { Responden }\end{array}$} & \multirow[b]{2}{*}{ Kesimpulan } \\
\hline & & $\begin{array}{c}\text { Skor 1 } \\
\text { (tidak efektif) }\end{array}$ & $\begin{array}{c}\text { Skor } 2 \\
\text { (cukup efektif) }\end{array}$ & $\begin{array}{c}\text { Skor 3 } \\
\text { (efektif) }\end{array}$ & & \\
\hline 1. & $\begin{array}{l}\text { mengadakan } \\
\text { pertemuan diantar } \\
\text { peternak }\end{array}$ & $\begin{array}{c}27, \text { jadi } \\
27 \times 16= \\
432\end{array}$ & $\begin{array}{l}62, \text { jadi } \\
62 \times 32 \\
=1984\end{array}$ & $\begin{array}{c}5, \text { jadi } \\
5 \times 48= \\
240\end{array}$ & 2656 & Cukup efektif \\
\hline 2. & \begin{tabular}{ll}
\multicolumn{2}{l}{ menampung } \\
aspirasi peternak \\
terkait harapan \\
peternak dalam \\
sektor persusuan
\end{tabular} & $\begin{array}{c}13 \text { jadi } \\
13 \times 16= \\
208\end{array}$ & $\begin{array}{l}72, \text { jadi } \\
72 \times 32 \\
=2304\end{array}$ & $\begin{array}{c}9, \text { jadi } \\
9 \times 48= \\
432\end{array}$ & 2944 & Cukup efektif \\
\hline 3. & $\begin{array}{l}\text { mengadakan } \\
\text { pertemuan dengan } \\
\text { stakeholder yang } \\
\text { terlibat dalam klaster }\end{array}$ & $\begin{array}{c}39, \text { jadi } \\
39 \times 16= \\
624\end{array}$ & $\begin{array}{l}55, \text { jadi } \\
55 \times 32 \\
=1760\end{array}$ & $\begin{array}{c}0, \text { jadi } \\
0 \times 48= \\
0\end{array}$ & 2384 & Cukup efektif \\
\hline \multicolumn{5}{|c|}{ Rata-rata } & 2661 & Cukup efektif \\
\hline
\end{tabular}

Dari penilaian efektivitas peran Bina Swadaya dalam kontrol kebijakan pemerintah dinilai cukup efektif. Namun pada kegiatan pertemuan dengan stakeholder persusuan, sebanyak 39 peternak memberikan penilaian tidak efektif, hal ini karena peternak beranggapan bahwa belum ada respon yang diberikan pemerintah terkait dengan kebijakan yang diberlakukan dalam klaster susu sapi perah, khususnya untuk harga susu dan jaringan pasar

- Peran Mikro

a. Memberikan akses pemasaran

Memberikan akses pemasaran merupakan salah satu upaya yang dilakukan Bina Swadaya untuk memperbaiki kondisi ekonomi peternak karena selama ini para peternak hanya mendistribusikan produksi susu ke KUD. Dengan melakukan kerjasama bersama Majalah Trubus yang merupakan salah satu produk Bina Swadaya, diharapkan dapat menjadi media pemasaran terhadap produk susu yang dihasilkan. Dalam peranan ini Bina Swadaya melakukan kegiatan seperti menciptakan relasi dengan Majalah Trubus serta menghubungkan klaster dengan informasi pameran produk klaster. Berikut merupakan penilaian efektivitas peran Bina Swadaya dalam memberikan akses pemasaran dalam klaster susu sapi perah:

Tabel 8. Penilaian Efektivitas Peran Bina Swadaya dalam Memberikan Akses Pemasaran

\begin{tabular}{|c|c|c|c|c|c|c|}
\hline \multirow[b]{2}{*}{ No. } & \multirow[b]{2}{*}{$\begin{array}{l}\text { Kegiatan yang } \\
\text { dilakukan }\end{array}$} & \multicolumn{3}{|c|}{ Penilaian Efektivitas Responden } & \multirow[b]{2}{*}{$\begin{array}{l}\text { Total Skor } \\
\text { Responden }\end{array}$} & \multirow[b]{2}{*}{ Kesimpulan } \\
\hline & & $\begin{array}{c}\text { Skor 1 } \\
\text { (tidak efektif) }\end{array}$ & $\begin{array}{c}\text { Skor 2 } \\
\text { (cukup efektif) }\end{array}$ & $\begin{array}{c}\text { Skor 3 } \\
\text { (efektif) }\end{array}$ & & \\
\hline 1. & $\begin{array}{l}\text { menciptakan relasi } \\
\text { dengan majalah }\end{array}$ & $\begin{array}{c}7, \text { jadi } \\
7 \times 16=\end{array}$ & $\begin{array}{l}61, \text { jadi } \\
61 \times 32\end{array}$ & $\begin{array}{l}26, \text { jadi } \\
26 \times 48=\end{array}$ & 3312 & Efektif \\
\hline 2. & $\begin{array}{l}\text { menghubungkan } \\
\text { klaster dengan } \\
\text { informasi pameran } \\
\text { produk klaster }\end{array}$ & $\begin{array}{c}9 \text { jadi } \\
9 \times 16= \\
144\end{array}$ & $\begin{array}{l}77, \text { jadi } \\
77 \times 32 \\
=2464\end{array}$ & $\begin{array}{c}8, \text { jadi } \\
8 \times 48= \\
384\end{array}$ & 2992 & Cukup efektif \\
\hline \multicolumn{5}{|c|}{ Rata-rata } & 3152 & Efektif \\
\hline
\end{tabular}




\section{Peran Non Governmental Organization (GIZ dan LSM Bina Swadaya) terhadap Klaster Susu Sapi Perah}

Dari penilaian efektivitas yang dilakukan di atas, diketahui peran yang dilakukan Bina dalam memberikan akses pemasaran dinilai efektif. Hal ini karena peranan yang dilakukan Bina Swadaya terkait akses pemasaran dirasa bagi peternak memberikan dampak yang cukup baik karena dapat membantu para peternak untuk mempromosikan produk yang dihasilkan sektor persusuan di Kabupaten Boyolali.

\section{b. Pengembangan kemandirian lembaga}

Mengembangkan kemandirian lembaga yang dilakukan Bina Swadaya dalam klaster ditujukan untuk dapat mendukung klaster melalui perkuat kelembagaan dalam klaster. Dalam pengembangan kemandirian lembaga ini, Bina Swadaya melakukan kegiatan yaitu mengadakan pertemuan dengan forum klaster dan FEDEP, melakukan monitoring dan evaluasi dari kegiatan yang telah dilakukan, serta memberikan motivasi kepada lembaga klaster untuk dapat meningkatkan sektor persusuan. Berikut penilaian efektivitas yang dilakukan Bina Swadaya dalam peran mengembangkan kemandirian lembaga:

Tabel 9. Penilaian Efektivitas Peran Bina Swadaya dalam Mengembangkan Kemandirian Lembaga

\begin{tabular}{|c|c|c|c|c|c|c|}
\hline \multirow[b]{2}{*}{ No. } & \multirow[b]{2}{*}{$\begin{array}{c}\text { Kegiatan yang } \\
\text { dilakukan }\end{array}$} & \multicolumn{3}{|c|}{ Penilaian Efektivitas Responden } & \multirow[b]{2}{*}{$\begin{array}{l}\text { Total Skor } \\
\text { Responden }\end{array}$} & \multirow[b]{2}{*}{ Kesimpulan } \\
\hline & & $\begin{array}{c}\text { Skor 1 } \\
\text { (tidak efektif) }\end{array}$ & $\begin{array}{c}\text { Skor 2 } \\
\text { (cukup efektif) }\end{array}$ & $\begin{array}{c}\text { Skor 3 } \\
\text { (efektif) }\end{array}$ & & \\
\hline 1. & $\begin{array}{l}\text { mengadakan } \\
\text { pertemuan dengan } \\
\text { forum klaster dan } \\
\text { FEDEP }\end{array}$ & $\begin{array}{c}7, \text { jadi } \\
7 \times 16= \\
112\end{array}$ & $\begin{array}{l}81, \text { jadi } \\
81 \times 32 \\
=2592\end{array}$ & $\begin{array}{c}6, \text { jadi } \\
6 \times 48= \\
288\end{array}$ & 2992 & Cukup efektif \\
\hline 2. & $\begin{array}{ll}\text { melakukan } & \\
\text { monitoring dan } \\
\text { evaluasi dari } \\
\text { kegiatan yang telah } \\
\text { dilakukan }\end{array}$ & $\begin{array}{c}0 \text { jadi } \\
0 \times 16= \\
0\end{array}$ & $\begin{array}{l}76, \text { jadi } \\
76 \times 32 \\
=2432\end{array}$ & $\begin{array}{c}18, \text { jadi } \\
18 \times 48= \\
864\end{array}$ & 3296 & Efektif \\
\hline 3. & \begin{tabular}{ll}
\multicolumn{2}{l}{ memberikan } \\
motivasi kepada \\
lembaga klaster \\
untuk dapat \\
meningkatkan \\
sektor persusuan
\end{tabular} & $\begin{array}{c}11 \text { jadi } \\
11 \times 16= \\
176\end{array}$ & $\begin{array}{l}75, \text { jadi } \\
75 \times 32 \\
=2400\end{array}$ & $\begin{array}{c}8, \text { jadi } \\
8 \times 48= \\
384\end{array}$ & 2960 & Cukup efektif \\
\hline \multicolumn{5}{|c|}{ Rata-rata } & 3003 & Cukup efektif \\
\hline
\end{tabular}

Dari penilaian efektivitas diatas, peran Bina Swadaya dalam peran pengembangan kemandirian lembaga dinilai cukup efektif. Monitoring yang dilakukan Bina Swadaya terhadap pengurus klaster dan FEDEP ditujukan untuk dapat mengembangkan dan meningkatkan kinerja pengurus menjadi lebih baik lagi. Namun ada dampak yang terjadi yaitu dengan adanya monitoring yang dilakukan, sedikit banyaknya dapat membantu pengurus untuk lebih meningkatkan kinerjanya dari evaluasi kinerja yang telah dilakukan sebelumnya.

c. Pemberdayaan peternak

Pemberdayaan pelaku usaha dilakukan untuk dapat melibatkan peternak dalam setiap kegiatan yang dilakukan klaster. Pelibatan peternak dalam setiap kegiatan dalam klaster ditujukan agar peternak dapat meningkatkan dan memperbaiki kondisi persusuan sehingga peternak dapat membuat suatu rencana kegiatan pengembangan klaster. Dalam peran pemberdayaan peternak ini. Bina Swadaya melakukan kegiatan seperti melibatkan peternak dalam identifikasi masalah dalam klaster, melakukan kunjungan langsung ke kandang peternak, melakukan transfer pengetahuan dan sosialisasi terkait dengan budidaya sapi perah, serta mengadakan pertemuan dengan peternak untuk dapat berbagi 
pengalam diantar peternak. Berikut penilaian efektivitas peran yang dilakukan GIZ dalam pemberdayaan pelaku usaha:

Tabel 10. Penilaian Efektivitas Peran Bina Swadaya dalam Pemberdayaan Peternak

\begin{tabular}{|c|c|c|c|c|c|c|}
\hline \multirow[b]{2}{*}{ No. } & \multirow[b]{2}{*}{$\begin{array}{c}\text { Kegiatan yang } \\
\text { dilakukan }\end{array}$} & \multicolumn{3}{|c|}{ Penilaian Efektivitas Responden } & \multirow[b]{2}{*}{$\begin{array}{l}\text { Total Skor } \\
\text { Responden }\end{array}$} & \multirow[b]{2}{*}{ Kesimpulan } \\
\hline & & $\begin{array}{c}\text { Skor 1 } \\
\text { (tidak efektif) }\end{array}$ & $\begin{array}{c}\text { Skor 2 } \\
\text { (cukup efektif) }\end{array}$ & $\begin{array}{c}\text { Skor 3 } \\
\text { (efektif) }\end{array}$ & & \\
\hline 1. & $\begin{array}{ll}\text { melibatkan } & \\
\text { peternak dalam } \\
\text { identifikasi } \\
\text { masalah }\end{array}$ & $\begin{array}{c}7, \text { jadi } \\
7 \times 16= \\
112\end{array}$ & $\begin{array}{l}81, \text { jadi } \\
81 \times 32 \\
=2592\end{array}$ & $\begin{array}{c}6, \text { jadi } \\
6 \times 48= \\
288\end{array}$ & 2992 & Cukup efektif \\
\hline 2. & $\begin{array}{l}\text { melakukan } \\
\text { kunjungan } \\
\text { langsung ke } \\
\text { kandang peternak }\end{array}$ & $\begin{array}{c}13 \text { jadi } \\
13 \times 16= \\
208\end{array}$ & $\begin{array}{l}72, \text { jadi } \\
72 \times 32 \\
=2304\end{array}$ & $\begin{array}{c}9, \text { jadi } \\
9 \times 48= \\
432\end{array}$ & 2944 & Cukup efektif \\
\hline 3. & $\begin{array}{l}\text { melakukan transfer } \\
\text { pengetahuan dan } \\
\text { sosialisasi terkait } \\
\text { dengan budidaya } \\
\text { sapi perah }\end{array}$ & $\begin{array}{c}15 \text { jadi } \\
15 \times 16= \\
240\end{array}$ & $\begin{array}{l}68, \text { jadi } \\
68 \times 32 \\
=2176\end{array}$ & $\begin{array}{c}11, \text { jadi } \\
11 \times 48= \\
528\end{array}$ & 2944 & Cukup efektif \\
\hline 4. & \begin{tabular}{lr}
\multicolumn{2}{l}{ Mengadakan } \\
pertemuan & dengan \\
peternak & untuk \\
dapat & berbagi \\
pengalam & diantar \\
peternak & \\
\end{tabular} & $\begin{array}{c}9 \text { jadi } \\
9 \times 16= \\
144\end{array}$ & $\begin{array}{l}79, \text { jadi } \\
79 \times 32 \\
=2528\end{array}$ & $\begin{array}{c}6, \text { jadi } \\
6 \times 48= \\
288\end{array}$ & 2960 & Cukup efektif \\
\hline \multicolumn{5}{|c|}{ Rata-rata } & 2960 & Cukup efektif \\
\hline
\end{tabular}

Dari penilaian efektivitas peran di atas, dinilai bahwa peran Bina Swadaya dalam pemberdayaan pelaku usaha dinilai cukup efektif. Dalam setiap kegiatan yang dilakukan Bina Swadaya terkait dengan pemberdayaan peternak dalam klaster dinilai memberikan dampak bagi klaster meskipun dampak yang dirasakan masih kecil. Untuk kegiatan pelibatan peternak dalam tahap identifikasi masalah dalam klaster dapat memberikan kontribusi tersendiri bagi para peternak untuk dapat meningkatkan dan mengembangkan klaster. Sementara itu, untuk kegiatan kunjungan langsung ke kandang ternak dapat memberikan pengetahuan secara langsung kepada peternak dalam melakukan budidaya sapi perah yang baik. Serta kegiatan mengadakan pertemuan di antara peternak membuat para peternak tidak terisolasi dari informasi luar dan meminimalisir kesenjangan sosial.

\section{Sintesis Peran dan Efektivitas Peran yang dilakukan NGO (GIZ dan Bina Swadaya) dalam Klaster Susu Sapi Perah}

Dalam teknis pelaksanaannya, klaster susu sapi perah melibatkan kerjasama dengan GIZ dan Bina Swadaya yang merupakan suatu NGO (Non-Governmental Organization). Dalam keterlibatannya, kedua NGO tersebut memiliki peranan masing-masing. Dalam klaster susu sapi perah, NGO (GIZ dan Bina Swadaya) memiliki peranan mikro dan peranan makro. Peranan makro yang dilakukan GIZ dalam klaster yaitu berupa pembelaan hak pelaku usaha dalam klaster serta memberikan informasi yang menjadi masalah dalam klaster. Sementara itu peranan makro yang dilakukan Bina Swadaya dalam klaster yaitu berupa kontrol kebijakan pemerintah dalam klaster. Dari peranan makro yang dilakukan GIZ dan Bina Swadaya dinilai lebih berkontribusi peranan makro yang dilakukan oleh GIZ. Hal ini karena dalam peranan makro GIZ melakukan 2 peran yaitu pembelaan hak pelaku usaha dan pemberian informasi yang menjadi masalah dalam klaster, sedangkan dalam peranan makro Bina Swadaya hanya melakukan kontrol kebijakan pemerintah. Untuk 


\section{Peran Non Governmental Organization (GIZ dan LSM Bina Swadaya) terhadap Klaster Susu Sapi Perah}

peranan mikro yang dilakukan GIZ dalam klaster yaitu berupa peningkatan daya saing, pengembangan kemandirian lembaga, serta pemberdayaan peternak dalam klaster. Peranan mikro yang dilakukan Bina Swadaya dalam klaster yaitu pemberian akses pemasaran, pengembangan kemandirian lembaga, serta pemberdayaan peternak. Dalam peranan mikro ini kontribusi yang diberikan GIZ dan Bina Swadaya dalam klaster memiliki besaran yang sama. Dalam peranan mikro ini antara GIZ dan Bina Swadaya memiliki peranan yang sama yaitu mengembangkan kemandirian lembaga dan pemberdayaan klaster, namun fokus peran yang dilakukan GIZ dan Bina Swadaya berbeda dan implementasi peran yang dilakukan pun berbeda.

Untuk sintesis penilaian efektivitas peran yang dilakukan GIZ dan Bina Swadaya dalam klaster dapat dilihat pada tabel di bawah ini:

Tabel 11. Sintesis Efektivitas Peran yang Dilakukan GIZ dan Bina Swadaya dalam Klaster Susu Sapi Perah

\begin{tabular}{|c|c|c|c|c|}
\hline \multirow[b]{2}{*}{ No. } & \multirow{2}{*}{$\begin{array}{c}\text { Efektivitas } \\
\text { Peranan yang } \\
\text { Dilakukan }\end{array}$} & \multicolumn{2}{|c|}{ NGO yang Terlibat } & \multirow[b]{2}{*}{ Keterangan } \\
\hline & & GIZ & Bina Swadaya & \\
\hline 1 & $\begin{array}{l}\text { Efektivitas } \\
\text { Peranan Makro }\end{array}$ & $\begin{array}{l}\text { Berikut } \\
\text { efektivitas dari penilaian } \\
\text { makro yang dilakukan } \\
\text { GIZ yaitu: } \\
\text { - Pembelaan hak } \\
\text { peternak dalam klaster } \\
\rightarrow \text { dinilai cukup } \\
\text { efektif. } \\
\text { - Memberikan } \\
\text { informasi yang } \\
\text { menjadi masalah } \\
\text { dalam klaster } \rightarrow \\
\text { dinilai cukup efektif }\end{array}$ & $\begin{array}{l}\text { Berikut } \\
\text { efektivitas dari penilaian } \\
\text { makro yang dilakukan } \\
\text { Bina Swadaya yaitu } \\
\text { kontrol } \quad \text { kebijakan } \\
\text { pemerintah terkait } \\
\text { dengan klaster susu. } \\
\text { Dalam peranan ini } \\
\text { dinilai cukup } \\
\text { efektif }\end{array}$ & $\begin{array}{l}\text { Dari penilaian efektivitas } \\
\text { peranan makro yang dilakukan } \\
\text { GIZ dan Bina Swadaya dapat } \\
\text { dinilai cukup efektif. Masih } \\
\text { belum optimalnya peran yang } \\
\text { dilakukan sehingga dampak } \\
\text { yang dirasakan pun masih kecil. } \\
\text { Hal ini karena dalam } \\
\text { mengimplementasikan perannya } \\
\text { GIZ dan Bina Swadaya memiliki } \\
\text { kekurangan dan kendala sendiri. } \\
\text { Dalam mengimplementasi peran } \\
\text { kontrol kebijakan pemerintah } \\
\text { memiliki kendala dimana dalam } \\
\text { klaster susu sapi perah } \\
\text { pemerintah hanya bertindak } \\
\text { sebagai fasilitator dan untuk } \\
\text { nilai susu ditentukan oleh } \\
\text { pemerintah nasional. }\end{array}$ \\
\hline 2 & $\begin{array}{l}\text { Efektivitas Peranan } \\
\text { Mikro }\end{array}$ & $\begin{array}{l}\text { Berikut } \text { penilaian } \\
\text { efektivitas dari peranan } \\
\text { mikro yang dilakukan } \\
\text { GIZ yaitu: } \\
\text { - Peningkatan daya } \\
\text { saing } \rightarrow \text { dinilai efektif } \\
\text { - Pengembangan } \\
\text { kemandirian lembaga } \\
\rightarrow \text { dinilai cukup } \\
\text { efektif } \\
\text { - Pemberdayaan } \\
\text { peternak } \rightarrow \text { dinilai } \\
\text { cukup efektif }\end{array}$ & $\begin{array}{l}\text { Berikut penilaian } \\
\text { efektivitas dari peranan } \\
\text { mikro yang dilakukan } \\
\text { Bina Swadaya yaitu: } \\
\text { - Memberikan akses } \\
\text { pemasaran } \rightarrow \text { dinilai } \\
\text { efektif } \\
\text { - Pengembangan } \\
\text { kemandirian lembaga } \\
\rightarrow \text { dinilai cukup } \\
\text { efektif } \\
\text { - Pemberdayaan } \\
\text { peternak } \rightarrow \text { dinilai } \\
\text { cukup efektif }\end{array}$ & $\begin{array}{l}\text { Dari penilaian } r \text { efektivitas } \\
\text { peranan mikro yang dilakukan } \\
\text { GIZ dan Bina Swadya, hampir } \\
\text { setiap peranan yang dilakukan } \\
\text { dinilai cukup efektif. Namun } \\
\text { untuk peranan yang dilakukan } \\
\text { GIZ terkait dengan peningkatan } \\
\text { daya saing melalui pengolahan } \\
\text { pasca produksi keju dinilai } \\
\text { efektif karena dapat } \\
\text { meningkatkan nilai susu. } \\
\text { Sedangkan peran Bina Swadaya } \\
\text { dalam memberikan akses } \\
\text { pemasaran juga dinilai efektif } \\
\text { karena dengan peran yang } \\
\text { dilakukan Bina Swadaya ini } \\
\text { dapat membantu para peternak } \\
\text { masuk dalam jaringan pasar }\end{array}$ \\
\hline
\end{tabular}

\section{Analisis Dampak Peranan NGO (GIZ dan Bina Swadaya) dalam Klaster}

Berdasarkan penilaian efektivitas yang dilakukan GIZ dan Bina Swadaya dalam klaster susu sapi perah, sebagian besar peran yang dilakukan NGO tersebut dirasa cukup efektif. Hal ini 
karena belum keseluruhan peternak sapi perah di Kabupaten Boyolali merasakan dampak dari peranan yang dilakukan GIZ dan Bina Swadaya dalam klaster. Namun secara langsung dampak dari keterlibatan GIZ dan Bina Swadaya dapat dinilai yaitu dari dampak sosial, dampak ekonomi, serta dampak kemasyarakatan (Ismawan, 2003). Berikut dampak sosial, ekonomi, dan kemasyarakatan dari keterlibatan GIZ dan Bina Swadaya dalam klaster susu sapi perah:

a. Dampak sosial

Dampak sosial dari keterlibatan NGO dalam klaster susu sapi perah yaitu berupa peningkatan pengetahuan dan wawasan yang diberikan oleh NGO seperti GIZ dan Bina Swadaya. Melalui pengetahuan yang diberikan di tingkat peternak, diharapkan para peternak dapat memperbaiki kondisi persusuan ini baik dari kualitas susu maupun produksi susu. Peningkatan pengetahuan yang diberikan oleh NGO dapat melalui dua jalur yaitu jalur langsung dan jalur tidak langsung. Peningkatan pengetahuan melalui jalur langsung seperti pemberian pelatihan, penyuluhan, serta sosialisasi. Sementara itu peningkatan pengetahuan melalui jalur tidak langsung yaitu seperti membentuk kelompok dan mengadakan pertemuan rutin antar sesama peternak dalam klaster. Dari pertemuan tersebut memberikan pengetahuan melalui sharing atau berbagi pengalaman antar sesama peternak. Selain itu, dalam pertemuan tersebut juga dapat membahas dan merumuskan kegiatan-kegiatan yang akan dilakukan ke depan agar dapat mengembangkan klaster susu sapi perah. Pembinaan dan pendampingan yang dilakukan oleh GIZ dan Bina Swadaya dalam klaster susu sapi perah dapat membantu para peternak untuk memecahkan permasalahan yang ada dalam klaster serta dapat melibatkan peternak secara aktif dalam memecahkan permasalahan tersebut.

b. Dampak ekonomi

Dampak ekonomi dari keterlibatan GIZ dan Bina Swadaya dalam klaster susu sapi perah yaitu adanya peningkatan harga jual susu yang terjadi dalam klaster susu sapi perah. Dimana dulu harga susu hanya Rp 1.000,- dan sekarang meningkat menjadi Rp 3.000,-. Dari peningkatan harga jual susu tersebut, secara langsung juga berpengaruh terhadap peningkatan peningkatan pendapatan para peternak. Meningkatnya harga jual susu juga dapat memberikan semangat tersendiri kepada para peternak dalam memproduksi susu. Selain peningkatan harga jual susu, intervensi pembinaan yang dilakukan GIZ dan Bina Swadaya juga menekankan pada peningkatan kualitas susu. Selain menjual susu segar, sektor persusuan di Kabupaten Boyolali juga membuat suatu proses pengolahan pasca produksi dengan mengolah produk-produk berbahan baku susu seperti susu bubuk, permen susu, sabun susu, yoghurt, dan keju. Inovasi produk tersebut dilakukan oleh NGO khususnya GIZ dengan tujuan untuk dapat meningkatkan value dari susu agar income peternak sapi perah menjadi meningkat. Selain itu, intervensi pembinaan berupa penciptaan relasi atau menghubungkan informasi luar yang dilakukan oleh Bina Swadaya membuka peluang dan akses pemasaran bagi para peternak. Penciptaan relasi dengan memberikan akses infromasi pasar membuat para peternak untuk aktif dalam mencari informasi mengenai akses pasar.

c. Dampak masyarakat

Dampak kemasyarakatan yang terjadi dari keterlibatan GIZ dan Bina Swadaya dalam klaster yaitu melalui intervensi pembinanaan dalam kelompok peternak. Interaksi di dalam kelompok secara tidak langsung dapat meningkatkan pengetahuan di tingkat peternak karena sebagian besar peternak sapi perah di Kabupaten Boyolali masih berpendidikan rendah sehingga dibuat suatu kelompok ternak. Pembentukan kelompok ternak bertujuan agar para peternak dapat saling berinteraksi dan berbagi pengalaman yang ada. Adanya keterlibatan aktif para peternak di dalam kelompok terutama pada saat mengadakan pertemuan memberikan kontribusi yang besar dalam pengembangan klaster. Pertemuan 
yang dilakukan antar sesama kelompok peternak bertujuan untuk membuat suatu rumusan kegiatan-kegiatan yang akan dilakukan dalam klaster. Oleh karena itu, para peternak dituntut untuk dapat berperan aktif dalam kegiatan klaster. Dari kesediaan peternak untuk dapat berperan aktif dalam klaster memberikan kontribusi yang cukup besar bagi perkembangan klaster susu sapi perah. Pelibatan peternak secara langsung dalam setiap kegiatan klaster berpengaruh dalam meminimalisir terjadinya kesenjangan sosial antar sesama peternak.

\section{Kesimpulan}

Keterlibatan GIZ dalam klaster lebih kepada pendampingan secara teknis karena GIZ dalam klaster bertindak sebagai technical assistent, sedangkan Bina Swadaya dalam klaster lebih terfokus pada pemberdayaan pelaku usaha melalui proses pendampingan. Kesimpulan yang dapat diambil dari penelitian mengenai Peran Non-Governmental Organization (GIZ dan LSM Bina Swadaya) dalam Klaster Susu Sapi Perah di Kabupaten Boyolali, yaitu:

- Peranan yang dilakukan GIZ dan Bina Swadaya dalam klaster terdiri dari peranan makro dan peranan mikro. Dari peranan makro yang dilakukan lebih banyak kontribusi yang diberikan GIZ dibandingkan dengan Bina Swadaya. Sedangkan untuk peranan mikro yang dilakukan GIZ dan Bina Swadaya memberikan kontribusi yang sama karena peranan yang dilakukan dalam peranan mikro sama besarnya;

- Dari penilaian efektivitas peranan makro yang dilakukan GIZ dan Bina Swadaya dapat dinilai bahwa peranan yang dilakukan GIZ lebih efektif dibandingkan dengan peranan yang dilakukan Bina Swadaya. Adanya kendala atau hambatan yang dirasakan Bina Swadaya dalam mencapai efektivitas dalam hal kontrol kebijakan pemerintah. Sementara itu penilaian efektivitas peranan mikro yang dilakukan GIZ dan Bina Swadaya, hampir setiap peranan yang dilakukan dinilai cukup efektif. Namun untuk peranan yang dilakukan GIZ terkait dengan peningkatan daya saing melalui pengolahan pasca produksi keju dinilai efektif karena dapat meningkatkan nilai susu.

- Dari dampak sosial yang terjadi, kontribusi dari GIZ yaitu pada peranan pembelaan hak pelaku usaha dan pemberdayaan peternak dalam klaster, sedangkan kontribusi dari Bina Swadaya dalam membentuk dampak sosial yaitu dari peran yang berupa pemberdayaan peternak. Dalam dampak sosial ini kontribusi yang diberikan GIZ lebih besar dibandingkan dengan Bina Swadaya. Untuk dampak ekonomi kontribusi yang diberikan oleh GIZ dan Bina Swadaya hampir sama yaitu peranan GIZ berupa peningkatan daya saing sedangkan Bina Swadaya berupa memberikan akses pemasaran. Namun dari peranan tersebut lebih efektif peran yang dilakukan GIZ untuk memberikan dampak ekonomi bagi klaster. Serta dampak kemasyarakatan, kontribusi yang diberikan oleh GIZ dan Bina Swadaya sama besar. Peranan yang dilakukan GIZ dalam memberikan dampak ke masyarakat yaitu berupa memberikan informasi yang menjadi masalah dalam klaster dan mengembangkan kemandirian lembaga, sedangkan peranan yang dilakukan Bina Swadaya dalam memberikan dampak kemasyarakatan bagi klaster yaitu berupa kontrol kebijakan pemerintah dan mengembangkan kemandirian lembaga. 


\section{Rekomendasi}

Berdasarkan kesimpulan yang telah dilakukan diatas, maka dapat dibuat rekomendasi bagi pihak-pihak yang terlibat dalam klaster khususnya bagi Pemerintah, GIZ dan Bina Swadaya, serta peternak sapi perah. Berikut rekomendasi yang dapat peneliti berikan:

- Bagi pemerintah $\rightarrow$ sebaiknya pemerintah dapat lebih memperhatikan klaster susu sapi perah di Kabupaten Boyolali dengan membuat suatu regulasi untuk dapat melindungi keenam kecamatan persusuan. Hal ini dilakukan agar sektor persusuan di Kabupaten Boyolali dapat terus berkelanjutan karena melihat potensi dari sektor persusuan di Kabupaten Boyolali. Selain itu, diharapkan dari pemerintah dapat memberikan bantuan kepada peternak khususnya dalam pemberian pakan ternak. Hal ini karena mahalnya harga pakan yang ditanggung sendiri oleh peternak tidak sebanding dengan nilai jual susu yang didapat. Serta pemerintah juga dituntut untuk dapat memberikan akses kepada peternak dalam pemberian akses informasi keluar.

- Bagi NGO (GIZ dan Bina Swadaya) $\rightarrow$ sebaiknya NGO dapat melakukan kerjasama dengan semua pihak yang terlibat dalam klaster, karena mengingat banyaknya peternak sapi perah yang ada di Kabupaten Boyolali yang tidak mungkin apabila pendampingan yang dilakukan kepada peternak dibebankan pada satu NGO. Dengan kerjasama dan koordinasi yang baik diharapkan setiap peternak sapi perah di Boyolali mendapatkan peranan yang sama sehingga dapat meminimalisir terjadinya kesenjangan sosial di antara peternak.

- Bagi peternak sapi perah $\rightarrow$ sebaiknya peternak dapat memperhatikan prosedur budidaya sapi perah yang benar dari segi manajemen kandang yang baik, pemberian pakan, kebersihan ternak, serta proses pemerahan yang baik. Selain itu, dalam melakukan prosedur budidaya sapi perah, khususnya dalam proses pemerahan. Seperti memberikan sabun untuk mempermudah proses pemerahan. Selain cara tersebut akan mempengaruhi kualitas susu yang dihasilkan, cara tersebut juga dapat membahayakan konsumen karena zat dari sabun akan tercampur ke susu.

\section{Daftar Pustaka}

Anderson, Thomas dkk. 2004. The Cluster Policies Whitebook. Sweden: IKED

Assery, S. 2009. Mengukur Efektifitas Organisasi. Dalam Website Global Management. Diakses tanggal 8 Januari 2012 melalui http://globalmanagement.wordpress.com/2009/05/29/mengukur-efektifitasorganisasi/

Beer, Andrew. et.al. 2003. Developing Locally. Bristol : The Policy Press University of Bristol

Bokelmann, Wolfgang. 2007. Application of Value Chain Analysis in Development Cooperation: the Promotion of Milk Cluster Boyolali, Indonesia. Faculty Of Agriculture and Horticulture Humboldt Universitat Zu Berlin.

Creswell, Jhon.W. 2010. Research Desgin: Pendekatan Kualitatif, Kuantitatif, dan Mixed. Yogyakarta: Pustaka Pelajar

FPESD. 2006. Peran Pemerintah, Swasta, Perguruan Tinggi, LSM dan Media Dalam Pengembangan Klaster. Lokakarya Nasional Pengembangan Klaster dan Display Program 23 Klaster. Diakses tanggal 25 Oktober 2011 melalui http://www.pwk.ft.undip.ac.id/P5_Newest/download/wshop1/202FPESD_LGSP_CLUS TER SOLO.pdf

Ismawan, Bambang. 2003. Partisipasi Dan Dimensi Keswadayaan: Pengalaman Lsm Membangun Keswadayaan Masyarakat. Dalam Jurnal Ekonomi Rakyat Artikel - Th. II - No. 3 - Mei 2003. Diakses tanggal 2 Desember 2011 melalui www.ekonomirakyat.org 


\section{Peran Non Governmental Organization (GIZ dan LSM Bina Swadaya) terhadap Klaster Susu Sapi Perah}

Japan International Coorperation Agency (JICA). 2004. Studi Penguatan Kapasitas UKM di Republik Indonesia. Jakarta: KRI International Corp

Karsidi, Ravik. 2001. Peran Sosial LSM Dalam Era Otonomi Daerah. Dalam makalah tidak diterbitkan. Diakses tanggal 2 Januari 2012 melalui http://si.uns.ac.id/profil/uploadpublikasi/Kegiatan/195707071981031006ravik_5.pdf

Laporan Pertanggungjawaban Tenaga Ahli DED. 2009. Deutscher Entwicklungsdienst: Deutscher Entwicklungsdienst

Marshall, Alfred. 1919. Industry and Trade. London. Macmillan 1919

Porter, M. E. 1998. Clusters and the new economics of competition. Harvard Business Review. Boston

Praja, Ageng Nata. Distorsi Peran Lembaga Swadaya Masyarakat Dalam Perspektif Civil Society Di Kabupaten Grobogan. Tesis tidak diterbitkan. Program Studi Magister Ilmu Politik Universitas Diponegoro. Semarang

Rugendyke, Barbara. 2007. NGOs as Advocates for Development in aGlo balising World. Routledge: London and New York

Sforzi, Fabio. 1988. The Institutions of Local Development. IGU Series on Local Development. Italy: University of Torino

Sudjana. 1996. Metode Statistika. Bandung: Tarsito

Sugiyono. 2004. Metode Penilaian Kuantitatif, Kualitatifm dan R \& D. Bandung: Alfabeta

Swinburn, Gwen. et. al. (2006). Local Economic Development: A Primer Developing And Implementing Local Economic Development Strategies And Action Plans. Washington DC : World Bank

Tulus, Tambunan. 2006. Development of Small-and Medium-Scale Industry Clusters In Indonesia dalam Kadin Indonesia-Jetro.

Willis, Katie. 2005. Theories and Practices of Development. USA and Canada: Routledge 